\author{
Melnik, V.M. 1, 2 , Polovnikov, I.I. ${ }^{1}$, Poyda, O.I. 1, 2 , and Shepetko, E. M. 1,3 \\ 1 Ukrainian Technological Academy, Department for Modern Medical Technologies, \\ 19/5, Kurenivski Lane, Kyiv, 04073, Ukraine, \\ +380444682358, akademia92@ukr.net \\ ${ }^{2}$ Bohomolets National Medical University, Surgery Department No. 1 , \\ 17, Shevchenka Ave., Kyiv, 01030, Ukraine, \\ +380 44235 3116, qwerasd.v@ukr.net \\ ${ }^{3}$ Bohomolets National Medical University, Surgery Department No. 3, \\ 4a, Podvysotsky St., Kyiv, 01013, Ukraine, \\ +380 44529 3843, shepevegen@gmail.com
}

\title{
EXPERIMENTAL JUSTIFICATION OF INVAGINATIVE COMPRESSIVE INTESTINAL ANASTOMOSIS MODELING
}

Introduction. Modern circular staplers do not solve the problem of size-mismatched anastomosis. This mismatch leads to deformation of the anastomosis and disrupts healing processes, which often entails complications. Therefore, the problem of stapling size-mismatched anastomosis is actual and needs to be solved.

Problem Statement. Development and testing of device that forms anatomical and functional justified invaginative anastomosis of mismatched intestines offcuts on experimental animals.

Purpose. Experimental improvement of the technique for invaginative anastomosis of mismatched intestines offcuts modeling using a new device designed by the authors.

Materials and Methods. New device for invaginative compressive intestinal anastomosis modeling of mismatched intestines offcuts has been designed. In experiment conditions, methods for the most complicated ileocolic, ileorectal, colorectal anastomoses have been tested out on animals using the new designed device.

Results. Uncomplicated more physiologic healing process of the intestinal anastomosis and advisability of using the new designed device in clinics have been shown.

Conclusions. Compressive junction method is sufficient for intestinal anastomosis formation, because it provides physiologic process of reparation. The study of invaginative compressive intestinal anastomosis formed in experiment conditions between mismatched intestinal offcuts using the new designed device has shown its anatomical and physiological usability and applicability in clinical practice.

Keywords: staplers, intestinal anastomosis, and morphogenesis of anastomosis healing.

The desire of surgeons to improve and to unify the technique for formation of anastomosis as the most complicated and responsible stage of surgical intervention in operations on the stomach and intestines has contributed to the development and implementation of mechanical circular stapler devices into the practice of restorative surgery.

(C) MELNIK, V.M., POLOVNIKOV, I.I., POYDA, O.I., and SHEPETKO, E.M., 2018
There are two types of modern circular staplers. In one of them, metallic staple suture is used, while the other uses a device for compression joint. Common elements of the technique for the formation of "end to end" anastomosis for bracket and compression staplers are inversion and alignment of the edges of digestive tract offcuts with the surface of serous membranes. In this case, the mechanical forces that ensure stapling or activate the compression mechanism are 


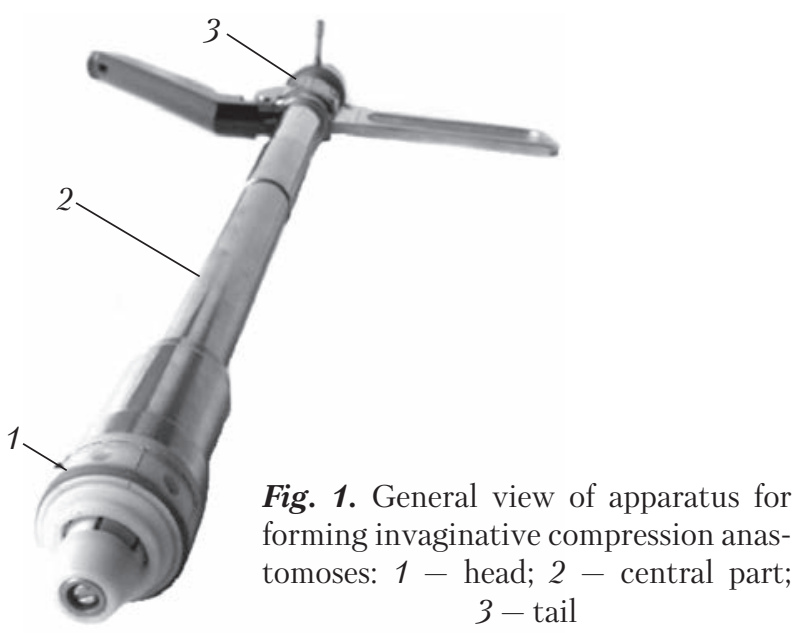

directed in a linear direction, parallel to the conventional axis of the digestive canal lumen.

The mechanical staple joint is characterized by disadvantages due to a significant number of complications, in particular, the suture failure in $3.8-14.6 \%$ of patients, as well as junction stricture in $3.6-17.6 \%$ of patients [1-5] The overwhelming majority of these complications arises due to chronic inflammatory process caused by prolonged, sometimes, life-long, stay of metal braces in the healing area.

The advantage of the compression joint over the mechanical brace joint is caused by the technological features of the method. The compression joint involves long-time mechanical compression of the edges of digestive canal offcuts between the device's circular surfaces having appropriate diameter. In this case, the compression force is $6.2-10.2 \mathrm{~g} / \mathrm{mm}^{2}$. In $7-8$ days, the tissue along the compression line necroses, with the compression mechanism separating and evacuating from the digestive canal lumen in a natural way. At the same time, in the mentioned period, the anastomosis outside the circular line of necrosis is completed. In this case, there are no foreign bodies in the area of anastomosis. This provides a more physiological healing without signs of inflammatory process. Therefore, in the case of compression anastomoses, the number of complications, in particular, the rate of suture failure and stricture is much smaller (2.7-4.2\%) $[1,5]$.

In spite of this, both types of circular stapling machines have a common significant disadvantage. They do not solve the problem of stapling offcuts of different diameters in the intestinal canal. Mismatch of the offcut diameters leads to the anastomosis deformation, inhibits the healing processes, which, in turn, causes frequent complications. Consequently, the problem of stapling the intestinal canal offcuts of different diameters with the help of devices is rather relevant and needs to be solved, in particular, by forming invaginative anastomoses.

The aim of this research is to experimentally improve the technology for forming anastomoses between the intestinal canal offcuts of different diameters by developing and using a new type of devices for the formation of invaginative anastomoses.

A device has been developed for the formation of invaginative anastomoses between the intestinal canal offcuts of different diameters, in particular, for small-large intestine anastomosis (patent No. 32278 A) [6]. This device is based on the compression method as more physiological than the metal brace suture. An apparatus for the formation of compressive invaginative anastomosis has been developed as well (patent No. 39575 A) [8]. It uses the above mentioned device as mechanism for invagination and compression. The apparatus consists of three main structural units: the head, the central part, and the tail (Fig. 1). The head of the apparatus (Fig. 2) is intended for fixing the offcuts of the digestive canal, their tight alignment, and stapling by compression. It contains corresponding elements for implementing these functions, in particular, fastener of the inlet offcut (1), extension of the fastener of the inlet offcut (2), auxiliary bearing rod (3), fastener of the outlet offcut (4), the main bearing rod (5), invaginator (6), ring-shaped extension of the invaginator (7), groove of the ring-shaped extension stopper (8), tooth-shaped edge of the invaginator (9), ring-shaped groove of the invaginator 
Fig. 2. The head of stapling apparatus: $1-$ fastener of the inlet offcut; 2 - extension of the fastener of the inlet offcut; 3 - auxiliary bearing rod; 4 - fastener of the outlet offcut; 5 - main bearing rod; 6 - invaginator; 7 - ring-shaped extension of the invaginator; 8 - groove of the ring-shaped extension stopper; 9 - tooth-shaped edge of the invaginator; 10 - ring-shaped groove of the invaginator; 11 - cam mechanism; 12 - compression ring

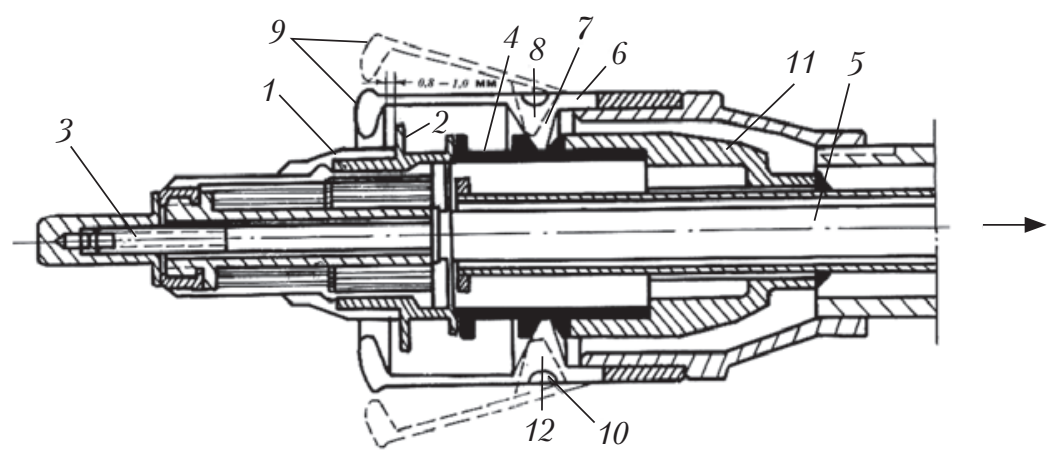

(10), cam mechanism (11), and compression ring (12). The central part of the apparatus (Fig. 3) has a unit for coupling the auxiliary and the main bearing rods (13) and the apparatus body (14). The tail part (Fig. 4) is represented by handle (15) and actuator (16).

The formation of invaginative compression anastomosis occurs as follows. To the fastener of the inlet offcut 1 located on the auxiliary bearing rod 3, the inlet offcut of the digestive canal is fixed with a cassette joint. To the fastener of the outlet offcut 4 located on the main bearing rod 5 , the outlet offcut is fixed in a similar way. The next step is to couple the auxiliary bearing rod 3 and the main bearing rod 5 in the junction 13. As a result, the attachment element of the inlet offcut 1 and the fastener of the outlet offcut 4 border to each other. Twisting the handle 15 of the actuator 6 makes both fasteners together with inlet and outlet offcuts fixed on them move, which is ensured by opening of the invaginator 6 , as a result of the movement of its ring-shaped extension 7 along the cam mechanism 11. As the fastener of inlet offcut 1 and the fastener of the outlet offcut 4 advance, the edges of the inlet and outlet offcuts are pushed into the cavity of the outlet offcut, the diameter of which is much larger. Thereafter, the ring-shaped extension of the invaginator 7 is downed into the stopper groove 8 located on the fastener of the outlet offcut 4 . As a results, the edges of the inlet and outlet offcuts are invaginated into the cavity of the outlet offcut to the required depth. Subse-

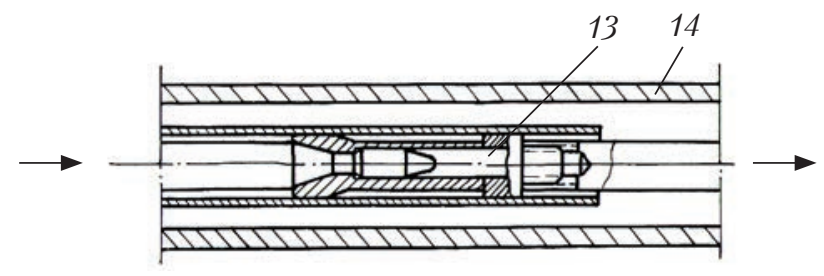

Fig. 3. The central part of the apparatus: 13 - a unit for coupling the auxiliary and the main bearing rods; $14-$ apparatus body

quently, the radially directed centripetal forces press the invaginated edges of the inlet and outlet offcuts between the extension of inlet offcut fastener 2 and the tooth-like edge of the invaginator 9. The radial centripetal compression is determined by elasticity of the compression ring 12 located in the ring groove of the invaginator 10 . Further twist of the handle 15 makes the interconnected auxiliary 3 and main 5 bearing rods move into the depth of the apparatus body 14 . Then, the invagination and compression mechanism that consists of the inlet offcut fastener 1 , the outlet offcut fastener 4 , the invaginator 6 , and the compression ring 12, remains in the cavity of the outlet offcut. The apparatus itself is removed outside.

It should be noted that in the invagination and compression mechanism is based on the developed method for coupling the digestive tract offcuts (patent No. 53532 A) [7]. The peculiarity of the method is that the compression of the edges of digestive canal offcuts is ensured by the compression force that acts at an angle of $45^{\circ}$ to 


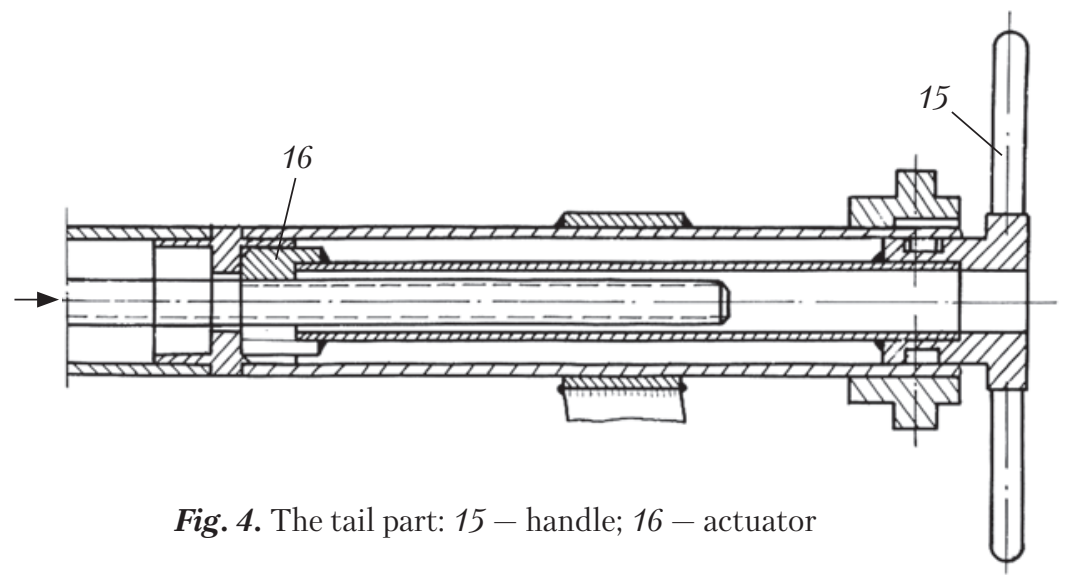

the center line instead of in linear direction. In this case, the compression is ensured by one-time force that compresses the digestive canal offcuts keeping the distance between the compressed surfaces within 1-1.2 mm instead of constant force. It has been proved that the specified distance between the compressed surfaces provides such a degree of compression of the intestinal canal offcuts, for which the compression duration is optimal for maintaining the physiological course of healing processes.

Under these circumstances, in 8-10 days, the walls of the intestinal canal offcuts start necrosing in the area of their largest compression, with the mentioned invagination and compression mechanism separating and removed through the anal canal lumen. Before the separation, the edges of the inlet and outlet offcuts grow together along the periphery from the line of necrosis. In this way, anastomosis is formed.

The developed apparatus has been tested on animals. In this case, 12 outbred male dogs have been operated. The average age of animals is 1 year and 3 months. ( \pm 4 months), the average weight is $21 \pm 3.7 \mathrm{~kg}$. The international Helsinki Declaration on Animal Use in Medical Research (2000) and Article 26 of Regulations for the Treatment of Animals Used in Research Experiments of the Law of Ukraine on the Protection of Animals from Cruel Treatment were strictly observed in the experiments [9]. In research, inter- stitial anastomoses (in particular, the method for the formation of small and large intestine anastomoses (patent No. 35277 A) [10], the method for the formation of ileorectal anastomosis (patent No. 47942 A) [11], and the method for the formation of colorectal anastomoses (patent No. 38948 A) [12]) that are more anatomically substantiated and more functionally advanced as compared with known analogs, have been developed. They are notable not only for the anatomical alignment of the intestinal canal offcuts of different diameters and more physiological course of healing processes, but also for the presence of an invaginated valve on the boundary of the inlet and outlet offcuts. The specified invaginated valve prevents the reflux from the cavity of the distal offcut into the cavity of the proximal offcut and pathological states caused by it.

Small-middle intestine anastomosis was created after right-sided hemicolectomy. The peculiarity of the technique for its formation was the endto-side coupling of small and middle offcuts, which corresponds to the anatomical structures of the human ileocecal part.

Ileorectal and colorectal anastomosis were formed end-to-end after colectomy and anterior resection of the rectum, respectively. Fig. 5 shows the formed invaginative compression colorectal anastomosis.

The formed anastomosis has been studied on 8th, 15th, and 30th days of postoperative period. 
The indicated terms correspond to the basic stages of healing of compression anastomosis, in particular, the separation of the compression device, the formation of loose connective tissue, and scar tissue. To this end, the anastomosis site was resected in the course of repeated surgical intervention, with new anastomosis formed between the offcuts of the intestinal canal, which remained after resection.

The area of resected anastomosis has been thoroughly examined on the side of abdominal cavity and intestine lumen. Its mechanical strength has been measured by the pneumatic pressure method. Specific features of healing have been studied using histological methods, using the Biolam system microscope with a lens magnification of $\times 20$ and that of ocular of $\times 5$. Microsections of anastomosis were stained with hematoxylin-eosin and picrofuxin by the Van Gyzon method.

On the 8th day of postoperative period, in each case, the compression device has already been separated. On the side of the abdominal cavity, there is intussusceptum in the form of circular thickening along the edge of the outlet offcut of the rectum. Its height from the wall of the invaginated inlet offcut is $2-3 \mathrm{~mm}$. From the side of lumen, the intussusceptum section is moderately swollen, has a shape of valve, the flap of which is located aborally (distally), in parallel with the wall of the outlet offcut. The healing line is located along the edge of the invaginate top, as a circular stripe of hyperemia. On the 15 th and, especially, on the 30th day of the postoperative period, on the side of abdominal cavity, the intussusceptum is barely visible as anastomosis swelling gets down. However, anastomosis is clearly visible in the area of the penetration of the inlet offcut into the outlet offcut cavity, due to the mismatch of their diameters. On the side of mucous membrane, in the apical part of the intussusceptum, there is a narrow, up to $1 \mathrm{~mm}$ wide, stripe of anastomosis, which differs from the mucous membrane by a lighter shade. In 2 cases (16.7\%), moderate flat adhesions appear, mainly,

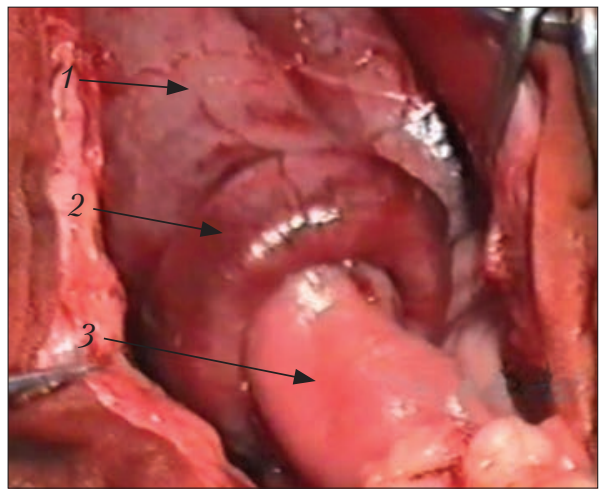

Fig. 5. Invaginative compression colorectal anastomosis: $1-$ outlet offcut of the rectum; 2 - invaginative anastomosis section; 3 - inlet section of the middle intestine

in the area of anastomosis, without any signs of deformation. On the side of lumen, the healing area is marked with a narrow light stripe of scar tissue completely covered by the intestinal epithelium.

The study of tightness of the formed anastomoses has showed their sufficient mechanical strength. On the third day of the postoperative period, they withstand a pressure of $158.4 \pm 5.7 \mathrm{~mm}$ $\mathrm{Hg}$, which is three times higher than the physiological pressure in the colon lumen. Further, the mechanical strength of the anastomoses is similar to that of the intestinal wall.

The results of the microscopic study of the formed anastomoses have showed that on the 8th day, there are observed a uniform dense adaptation of the walls of the intestinal offcuts in the area of their junction and their moderate thickening due to swelling. The thickness of the mucous membrane is slightly smaller, its edges are grown together, the crypts are deformed. The most significant changes in enterocytes are observed at the site of junction, where picnographic changes in the nuclei or their complete destruction are reported. In the healing area, there are observed an insignificant lymphoid infiltration, areas of muscle cell autolysis, and their replacement with a new connective tissue. There are many blood vessels and a noticeable deposi- 
tion of collagen and elastic fibers. Macro-vessels are expanded, full-blooded, which is a sign of compensatory congestion. In the area of serous membrane junction, there is an adhesion of young connective tissues, which is coated with the mesothelium from outside.

On the 15th day, in the area of anastomosis, the mucous membrane is less thick than the intestine walls. The enterocyte size and the crypt depth are also smaller. The muscle fibers in the joint area are replaced by a thin young connective tissue. This joint is covered with a serous membrane, from outside, and with a mucous membrane, rich in vessels of the microcirculatory bloodstream, from inside. There are reported an insignificant tissue swelling, lympho-histiocytic infiltration, and numerous collagen and elastic fibers.

On the 30th day, the thickness of the connective tissue in the joint area corresponds to that of the wall. There are thickening of the muscle layer and the presence of a young connective tissue with separate muscle fibers in the joint area.

Thus, the use of the developed apparatus for the formation of invaginative compression anastomoses solves the problem of the formation of anastomoses between the intestinal canal offcuts of different diameters by invagination of both offcuts into the cavity of the offcut with larger diameter and creating a centripetal compressive force. The specific features of the formation of invaginative compression anastomosis provide reproducing the anatomical parameters between the intestinal canal offcuts of different diameters, contribute to the physiological, uncomplicated reparative processes without foreign bodies in the junction site.

\section{CONCLUSIONS}

1. The method of compression stapling is sufficiently effective in the formation of anastomoses in the intestinal canal organs, since it provides the physiological course of reparative processes.

2. The formation of invaginative compression anastomoses between the intestinal canal offcuts of different diameters in the experimental conditions with the help of the developed apparatus has been shown to be adequately substantiated in terms of anatomical and functional considerations.

3. The results of experimental research have shown the feasibility of manufacturing the apparatus for its use in clinical practice.

The development, testing, and introduction into clinical practice of new, more advanced devices for stapling the intestinal canal offcuts are a promising direction of further research works.

\section{REFERENCES}

1. Tkachenko, F. G. (2004). Clinical and functional evaluation of anastomosis of the colon, created by different types of cross-linking devices. PhD (Med.). Kyiv [in Ukrainian].

2. Kumar, A., Daga, R., Vijayaragavan, P., Prakash, A., Singh, R. K., Behari, A., Kapoor, V. K., Saxena, R. (2011). Anterior resection for rectal carcinoma - risk factors for anastomotic leaks and strictures. WorldJ. Gastroenterol., 17(11), 1475-1479.

3. Maggiori, L., Bretagnol, F., Ferron, M., Chevalier, Y., Panis, Y. (2011). Laparoscopic colorectal anastomosis using the novel Chex circular stapler: case-control study. Colorectal Dis., 13(6), 711-715.

4. Pitel, S., Lefèvre, J. H., Tiret, E., Chafai, N., Parc, Y. (2012). Redo coloanal anastomosis: a retrospective study of 66 patients. Ann Surg., 256(5), 806-811.

5. Wallstein, C., Gross, E. (1999). Compression Anastomosis (AKA-2) in colorectal surgery: results in 442 consecutive patients. Br.J. Surg., 87(8), 1071-1075.

6. Patent of Ukraine № 35278. Melnik V. M., Poyda O. I., Kovalsky M. P., Bogdan K. S., Fatkov O. P. A device for the formation of ileocolonic anastomosis [in Ukrainian].

7. Patent of Ukraine № 53532. Melnik V. M. The method of connecting the segments of the digestive canal [in Ukrainian].

8. Patent of Ukraine № 39575. Melnik V. M., Poyda O. I., Shapovalov L. I., Bohdan K. S. Apparatus for formation of compressive invagination anastomoses [in Ukrainian]. 
9. The Law of Ukraine "On the Protection of Animals from Cruel Treatment". Information from the Verkhovna Rada of Ukraine. 2006. No. 27. p. 230.

10. Patent of Ukraine № 35277. Melnik V. M., Poyda O. I., Bohdan K. S. Method of formation of ileocolonic anastomosis [in Ukrainian].

11. Patent of Ukraine № 47942. Melnik V. M. Method of formation of ileorectal anastomosis [in Ukrainian].

12. Patent of Ukraine № 38948. Melnik V. M. Method of formation of colorectal anastomosis [in Ukrainian].

Received 05.01.18

\author{
В.М. Мельник ${ }^{1,2}$, I.I. Половніков ${ }^{1}$, О.І. Пойда ${ }^{1,2}$, C.М. Шепетько ${ }^{1,3}$ \\ ${ }^{1}$ Українська Технологічна Академія, відділення «Сучасні медичні технології», \\ пер. Куренівський, 19/5, Київ, 04073, Україна, \\ +380 44468 2358, akademia92@ukr.net \\ ${ }^{2}$ Національний медичний університет імені О.О. Богомольця, кафедра хірургії № 1 , \\ б-р Шевченка, 17, Київ, 01030, Україна, \\ +380 442353116 , qwerasd.v@ukr.net \\ ${ }^{3}$ Національний медичний університет імені О.О. Богомольця, кафедра хірургії № 3, \\ вул. Підвисоцького, 4а, Київ, 01013, Україна, \\ +380 44529 3843, shepevgen@gmail.com

\section{ЕКСПЕРИМЕНТАЛЬНЕ ОБГРУНТУВАННЯ ФОРМУВАННЯ ІНВАГІНАЦІЙНИХ КОМПРЕСІЙНИХ МІЖКИШКОВИХ АНАСТОМОЗІВ}

Вступ. Сучасні циркулярні зшиваючі апарати не вирішують проблему зшивання відрізків кишкового каналу різного діаметру. Невідповідність діаметру відрізків при формуванні анастомозів призводить до деформації ділянки з'єднання, порушує перебіг процесів загоєння, що обумовлює часте виникнення ускладнень. Отже, проблема з'єднання відрізків кишкового каналу різного діаметру за допомогою технічних пристроїв достатньо актуальна й потребує свого вирішення.

Проблематика. Розробка та апробація на експериментальних тваринах технічного пристрою для формування анатомічно і функціонально обгрунтованих інвагінаційних анастомозів між відрізками кишкового каналу різного діаметру.

Мета. Експериментальне вдосконалення техніки формування інвагінаційних анастомозів між відрізками кишкового каналу різного діаметру з використанням розробленого технічного пристрою нового типу.

Матеріали й методи. Розроблено апарат нового типу для формування інвагінаційних компресійних анастомозів між відрізками кишкового каналу різного діаметру. В умовах експерименту на тваринах з використанням зазначеного апарату відпрацьовано способи найбільш технічно складних тонко-ободовокишкового, ілеоректального та колоректального анастомозів.

Результати. Показано неускладнений, більш фізіологічний перебіг процесів загоєння міжкишкових анастомозів та доцільність використання розробленого апарату в умовах клінічної практики.

Висновки. Метод компресійного з'єднання достатньо ефективний при формуванні міжкишкових анастомозів оскільки забезпечує фізіологічність перебігу репаративних процесів. Дослідження міжкишкових інвагінаційних компресійних анастомозів зформованих в умовах експерименту між відрізками кишкового каналу різного діаметру за допомогою розробленого апарата вказує на достатню анатомічну та функціональну їх обгрунтованість та доцільність використання його в клінічній практиці.

Ключові слова: зшиваючі апарати, анастомози на органах кишкового каналу, морфогенез загоєння анастомозів. 
В.М. Мельник ${ }^{1,2}$, И.И. Половников ${ }^{1}$, А.И. Пойда ${ }^{1,2}$, Е.Н. Шепетько ${ }^{1,3}$

${ }^{1}$ Украинская Технологическая Академия, отделение «Современные медицинские технологии», пер. Куреневский, 19/5, Киев, 04073, Украина, +380 44468 2358, akademia92@ukr.net

${ }^{2}$ Национальный медицинский университет имени А.А. Богомольца, кафедра хирургии № 1 , бульв. Шевченка, 17, Киев, 01030, Украина, +380 442353116 , qwerasd.v@ukr.net

${ }^{3}$ Национальный медицинский университет имени А.А. Богомольца, кафедра хирургии № 3 , ул. Подвысоцкого, 4а, Киев, 01013, Украина, +380 44529 3843, shepevgen@gmail.com

\section{ЭКСПЕРИМЕНТАЛЬНОЕ ОБОСНОВАНИЕ ФОРМИРОВАНИЯ ИНВАГИНАЦИОННЫХ КОМПРЕССИОННЫХ МЕЖКИШЕЧНЫХ АНАСТОМОЗОВ}

Введение. Современные циркулярные сшивающие аппараты не решают проблему сшивания отрезков кишечного канала разного диаметра. Несоответствие диаметра отрезков при формировании анастомозов приводит к деформации области соединения, нарушает процессы сращивания, что способствует частому возникновению осложнений. Поэтому проблема соединения отрезков кишечного канала разного диаметра с помощью технических устройств достаточно актуальна и требует своего решения.

Проблематика. Разработка и апробация на экспериментальных животных технического устройства для формирования анатомически и функционально обоснованных инвагинационных анастомозов между отрезками кишечного канала разного диаметра.

Цель. Совершенствование техники формирования инвагинационных анастомозов между отрезками кишечного канала разного диаметра с использованием разработанного технического устройства нового типа.

Материалы и методы. Разработан аппарат нового типа для формирования инвагинационных компрессионных анастомозов между отрезками кишечного канала разного диаметра. В условиях эксперимента на животных с использованием указанного аппарата отработанны способы наиболее технически сложных тонко-ободочнокишечного, илеоректального и колоректального анастомозов.

Результаты. Показано неосложненное, более физиологическое течение процессов заживления межкишечных анастомозов и целесообразность использования разработанного аппарата в условиях клинической практики.

Выводы. Метод компрессионного соединения достаточно эффективен при формировании межкишечных анастомозов поскольку обеспечивает физиологичность течения репаративных процессов. Исследование инвагинационных компрессионных анастомозов, сформированных в условиях эксперимента между отрезками кишечного канала разного диаметра с помощью разработанного аппарата, указывает на достаточную анатомическую и функциональную их обоснованность и целесообразность его использования в клинической практике.

Ключевые слова: сшивающие аппараты, анастомозы на органах кишечного канала, морфогенез заживления анастомозов. 